Abstracta Iranica

Revue bibliographique pour le domaine irano-aryen

Volume 26 | 2005

Comptes rendus des publications de 2003

\title{
« NaH̆ostīn čāp-e dīvān-e Ḥāfez ». Našr-e Dāneš, 20, 1 (1382/2003), pp. 19-20.
}

\section{Charles-Henri de Fouchécour}

\section{(2) OpenEdition}

\section{Journals}

Édition électronique

URL : http://journals.openedition.org/abstractairanica/1802

ISSN : 1961-960X

Éditeur :

CNRS (UMR 7528 Mondes iraniens et indiens), Éditions de l'IFRI

Édition imprimée

Date de publication : 15 mai 2005

ISSN : 0240-8910

\section{Référence électronique}

Charles-Henri de Fouchécour, « « Nahostīn čāp-e dīvān-e Hāfez ». Našr-e Dāneš, 20, 1 (1382/2003),

pp. 19-20. », Abstracta Iranica [En ligne], Volume 26 | 2005, document 341, mis en ligne le 07 décembre 2005, consulté le 25 septembre 2020. URL : http://journals.openedition.org/abstractairanica/1802

Ce document a été généré automatiquement le 25 septembre 2020.

Tous droits réservés 


\title{
« NaH̆ostīn čāp-e dīvān-e Ḥāfez ». Našr-e Dāneš, 20, 1 (1382/2003), pp. 19-20.
}

\author{
Charles-Henri de Fouchécour
}

1 Le Dìvān de Ḥāfez fut imprimé pour la première fois à Calcutta en 1206/1791 par Abū Ṭāleb Tabrīzī Eșfahānī. C'était un Iranien résidant en Inde, homme d'affaires, homme politique et écrivain, célèbre en particulier pour son récit de voyage en Europe (masir-e țālebī), il fut aussi l'A. d'une fort intéressante anthologie des poètes et écrivains de son temps (Hulāṣat al-afkār), qui reste à éditer. Du monument de Ḥāfeẓ il fit une bonne édition critique, se fondant sur douze manuscrits de qualité. En introduction, il a fait le récit de ce long travail d'édition.

\section{INDEX}

Thèmes : 11.1.1. Littérature persane classique

Keywords : Divān-e Hāfez

nompropre Hafez, Abū Ṭāleb Tabrīzī Eṣfahānī, Eṣfahānī

\section{AUTEURS}

\section{CHARLES-HENRI DE FOUCHÉCOUR}

Fondateur de la revue Abstracta Iranica - Paris 